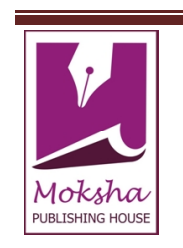

INTERNATIONAL RESEARCH JOURNAL OF PHARMACY

www.irjponline.com

ISSN $2230-8407$

Research Article

\title{
THERAPEUTIC POTENTIAL OF CARDIAC GLYCOSIDES OF CALOTROPIS GIGANTEA FOR BREAST CANCER
}

K. Sumangala Bhat* and Abhilasha Sharma

Department of Biotechnology, Acharya Institute of Technology, Acharya Dr. Sarvepalli Radhakrishnan Road, Bangalore, India

*Corresponding Author Email: sumangalabhat@acharya.ac.in

Article Received on: 12/03/13 Revised on: 07/04/13 Approved for publication: 11/05/13

DOI: 10.7897/2230-8407.04636

IRJP is an official publication of Moksha Publishing House. Website: www.mokshaph.com

(c) All rights reserved.

\section{ABSTRACT}

The present study deals with the cytotoxic activity of cardiac glycosides of Calotropis gigantea (L.) W.T.Aiton; on breast cancer cell line MCF-7. Qualitative screening of methenaloic extract of leaves of Calotropis gigantea for secondary metabolites showed the presence of phenolics, alkaloids, coumarins, saponins, tannins and glycosides. Glycosides were selected for detailed chemical analysis, anti-cancer and anti-proliferative activity. LC-MS analysis of the glycoside extract showed the presence of calactin (532.63), calotropin (532.63), cymarin (532.63) and asclepin (574.66) as the components along with three other glycosides yet to be identified. Cytotoxic activity of the glycosidic fraction was proved on MCF-7 cells through MTT assay, with $\mathrm{IC}_{50}$ value of $2.7 \mathrm{mg} / \mathrm{ml}$. Cardiac glycosides exhibited cell proliferation inhibition by inducing cells to undergo cell cycle arrest. The study has confirmed anticancer potential of cardiac glycosides from Calotropis gigantea. Further investigation on mechanism of cytotoxicity and action of individual components of the glycosidic fraction on cancer cells would help in identifying the real potential of the fraction as an anticancer drug.

Keywords: Calotropis gigantea, secondary metabolites, LC-MS, MTT assay, Anti-proliferation, $\mathrm{IC}_{50}$, cardiac glycosides.

\section{INTRODUCTION}

Cardiac glycosides are triterpene molecules that are complex in nature and exert biological effects on humans and other organisms. These molecules are often used therapeutically when dosed in minute quantities. Evidences of in vitro studies for the inhibition of malignant cell proliferation by cardiac glycosides started in late $1967^{1}$. Since then numerous other reports have been confirmed the anti proliferative and apoptotic effects of these compounds in several cancer cell lines including breast cancer ${ }^{2-4}$. Many plants are reported to contain cardiac glycosides and Calotropis procera is one of the important source plants ${ }^{5}$. The milky sap contains a complex mix of chemicals, some of which are steroidal heart poisons known as cardiac aglycones. These belong to the same chemical family found in foxgloves (Digitalis purpurea). The glycosides found in Calotropis procera are calotropin, calotoxin, calactin, uscharidin and voruscharin ${ }^{6}$. Previous studies ${ }^{7-9}$ have demonstrated potent cytotoxic activity of the flower of Calotropis procera and this was reported to be comparable to the anticancer effect of cisplastin. Anticancer effects of cardiac glycosides have been reported in several types of carcinoma, including breast cancer. Cardiac Glycosides induce apoptosis and disrupt numerous cellular processes vital to tumour growth, such as inhibition of proliferation, angiogenesis, cell migration and invasion. Current study involved the separation and identification of cardiac glycosides from Calotropis gigantea and in vitro analysis of their cytotoxic activity on breast cancer cell line MCF-7.

\section{MATERIALS AND METHODS}

\section{Collection and preparation of plant material}

Leaves of Calotropis gigantea [Collection No. Abhilasha Sharma, 69858, deposited in FRLHT, Bangalore] were collected from AIT, Bangalore campus, washed in tap water and shade dried for about two weeks at room temperature. The dried leaves were powdered and kept in air tight containers for further use.

\section{Preparation of extract}

$80 \mathrm{~g}$ of dried powdered leaf was percolated in $400 \mathrm{ml}$ methanol $(100 \%)$ in a 1 litre conical flask and shaken well for 4hours. The mixture was filtered through Whatman filter paper No.1. The filtrate was poured into porcelain crucibles and kept on a water bath at $80^{\circ} \mathrm{C}$ for evaporation of the solvent. The residue was collected weighed and stored at room temperature. This sample is called hereafter as Leaf Methanol Extract and abbreviated as LFM.

\section{Screening of secondary metabolite composition}

Phytochemical screening was carried out on the crude extract for the presence of phenolics, alkaloids, anthraquinones, coumarins, flavonoids, saponins and tannins by standard methods (Table 1).

\section{Extraction and isolation of cardiac glycosides}

Plant leaves were shade dried for 15days at room temperature. Dried leaves were crushed into fine powder. $100 \mathrm{gm}$ of leaf powder was macerated with $250 \mathrm{ml} 80 \%$ methanol. Mixture was dissolved with the help of magnetic stirrer for 5hours and extract was filtered using Whatman filter paper No.1. Filtrate was concentrated with the help of simple distillation by removing extra methanol. $6 \mathrm{~N} \mathrm{HCl}$ was added to the filtrate and mixed well. Mixture was kept in hot air oven at $180^{\circ} \mathrm{C}$ for 24 hours. Black sediment (Aglycones) was formed at the bottom of the vessel. Aglycone sample was filtered and dried in a hot air oven set at $30^{\circ} \mathrm{C}$. Dried aglycone sample was dissolved in $20 \mathrm{ml}$ of absolute ethanol and used for LC-MS analysis for identifying the compounds.

\section{LC-MS analysis}

LC-MS analysis was done on a Aglient 6401 Triplequad modular system. Analyses was done using ESI (electron source ionisation) interface. $1 \mathrm{ml}$ of sample was diluted to $5 \mathrm{ml}$ with methanol, mixed and filtered through 0.22 micron syringe filter. $10 \mu 1$ of sample was injected to the system and the mass detector was operated in a positive mode with nebulizer gas at the flow rate of $8 \mathrm{~L} / \mathrm{min}$ and temperature of 
the gas was maintained at $350^{\circ} \mathrm{C}$. Deflector voltage was $+4000 \mathrm{~V}$.

\section{Establishment of experimental cell culture}

MCF-7 cell lines were collected from NCCS (National Centre for Cell Sciences), Pune. Primary culture was grown first in $25 \mathrm{~cm}$ square tissue culture flask containing $5 \mathrm{ml}$ tissue culture medium (DMEM)] and sub cultured subsequently. Cell density in the subcultures was monitored by cell counting at regular intervals.

\section{MTT assay}

MCF-7 cells were seeded in $100 \mu$ DMEM medium with $10 \%$ FBS per well in a 96 well plate at a density of $5 \times 10^{3}$ and incubated it overnight at $37^{\circ} \mathrm{C} / 5 \% \mathrm{CO}_{2} .8 \mathrm{mg} / \mathrm{ml}$ stock of test sample was prepared in DMSO and was added in different concentrations $(0.025-4 \mathrm{mg} / \mathrm{ml})$ to cells in triplicate. Untreated cells were taken as negative control whereas $1 \mu \mathrm{g} / \mathrm{ml}$ doxorubicin was added to positive control. Incubation was done at $37^{0} \mathrm{C} / 5 \% \mathrm{CO}_{2}$ for 48 hours. $20 \mu \mathrm{l}$ of $5 \mathrm{mg} / \mathrm{ml}$ of MTT in PBS was added to each well and incubated at $37^{\circ} \mathrm{C} /$ $5 \% \mathrm{CO}_{2}$ for 4 hours. After aspiration of the medium $200 \mu \mathrm{l}$ of DMSO was added and optical density was measured at $570 \mathrm{~nm}$. Concentration vs. percentage inhibition of cell proliferation was plotted and $\mathrm{IC}_{50}$ was calculated.

\section{RESULTS}

Extraction of leaf powder with methanol has yielded $4.46 \%$ of crude LFM. The yield of cardiac glycoside fraction was $21 \%$ of the leaf powder. Results of the screening for secondary metabolites in LFM have indicated the presence of phenolics, alkaloids, coumarins, saponins, tannins and cardiac glycosides in the sample (Table1). LC/MS analysis of the cardiac glycoside fraction isolated from the leaves has yielded 6 compounds of which, 3 compounds have been identified based on molecular weight and available information in literature (Table 2) ${ }^{10,11}$. The effect of cardiac glycoside fraction on proliferation of MCF-7 cells was determined by MTT assay. Percentage inhibition of cell proliferation is plotted against concentration of the extract (Figure 1). The study has demonstrated increase in percentage inhibition of cell proliferation with increase in concentration of the extract. The $\mathrm{IC}_{50}$ value of the glycoside fraction was found to be $2.7 \mathrm{mg} / \mathrm{ml}$. Figure 2 illustrates the visible changes observed in the appearance of cells. The cells treated with test sample showed morphological changes similar to that of doxorubicin, known cytotoxic agent.

\section{DISCUSSION}

Current study has attempted molecular profiling of the glycoside fraction of Calotropis gigantea leaf and evaluation of its cytotoxicity on MCF 7 cells by MTT assay under in vitro conditions. Cardiac glycosides in general are known to induce growth inhibition in neoplastic cells and hence the glycoside fraction of the leaf of the plant has been selected for evaluating its potential as a cytotoxic agent on MCF 7 cells in the current investigation. LC/MS analysis of the test sample of glycosides has indicated the presence of calactin, calotropin, cymarin and asceplin. Of these, calactin is reported to cause DNA damage and apoptosis in human leukemia cells. Current study has confirmed the inducement of cell death by the glycoside sample from Calotropis gigantea on MCF-7cells with $\mathrm{LC}_{50}$ value of $2.7 \mathrm{mg} / \mathrm{ml}$. As the sample contains different compounds, some of them unknown, we can conclude that this is a potential source material for anticancer drug and further studies on the comparative efficacy of the molecules in inducing cytotoxicity, identification of unknown compounds, in vivo confirmatory studies on the cytotoxicity and possibility of use of the glycoside fraction as such or individual molecules, needs to be explored. 
K. Sumangala Bhat et al. Int. Res. J. Pharm. 2013, 4 (6)

Table 1: Qualitative profile of secondary metabolites of LFM

\begin{tabular}{|c|c|c|c|c|c|c|c|c|c|c|c|}
\hline \multirow{2}{*}{$\begin{array}{c}\text { Calotropis procera }+ \\
\text { solvent }\end{array}$} & \multicolumn{2}{|c|}{ Alkaloids } & \multicolumn{2}{|c|}{ Cardiac glycosides } & \multicolumn{2}{|c|}{ Anthroquione glycosides } & \multirow[t]{2}{*}{ Anthraquinones } & \multirow{2}{*}{$\begin{array}{c}\text { Saponins } \\
\text { [Foam test] }\end{array}$} & \multirow[t]{2}{*}{ Coumarins } & \multirow[t]{2}{*}{ Flavanoids } & \multirow[t]{2}{*}{ Tannin } \\
\hline & Dragendroff's & Mayer's & Legal's & Keller killiani & Borntrager's & Modified borntrager's & & & & & \\
\hline Leaf methanol extract & + & + & - & + & - & + & - & + & + & - & + \\
\hline
\end{tabular}

Table 2: Cardiac glycosides detected from leaf of Calotropis gigantea

\begin{tabular}{|c|c|c|}
\hline Retention time & Molecular weight & Probable compound \\
\hline 4.4 & 534.8 & Calactin or Calotropin or Cymarin \\
\hline 5.5 & 349 & \\
\hline 7.5 & 458 & \\
\hline 10.1 & 478.9 & \\
\hline 15 & 478.9 & Asceplin \\
\hline 19.8 & 576.8 & \\
\hline
\end{tabular}

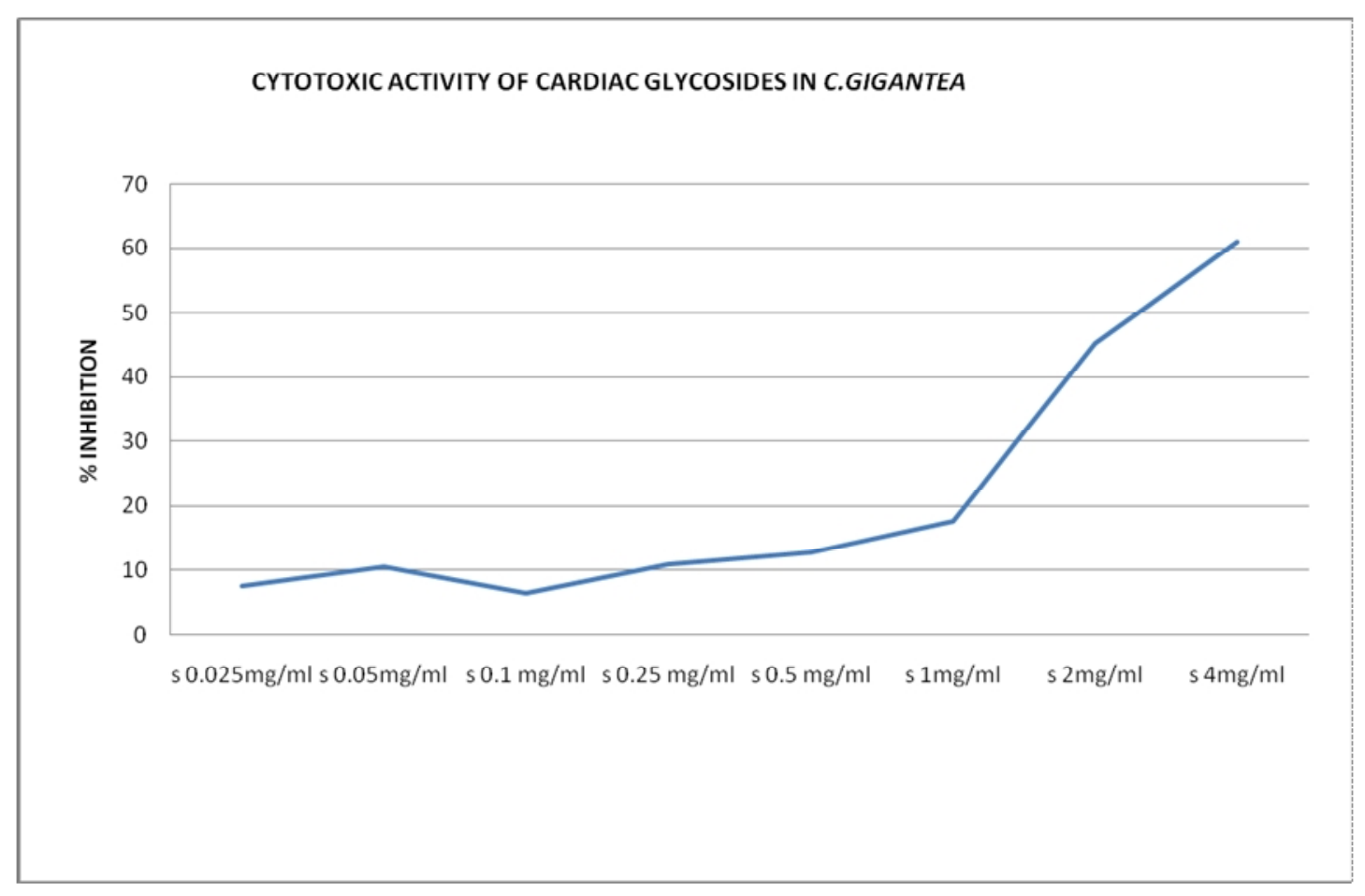

Figure 1: \% Inhibition of growth of cancer cells by glycosides extracts 

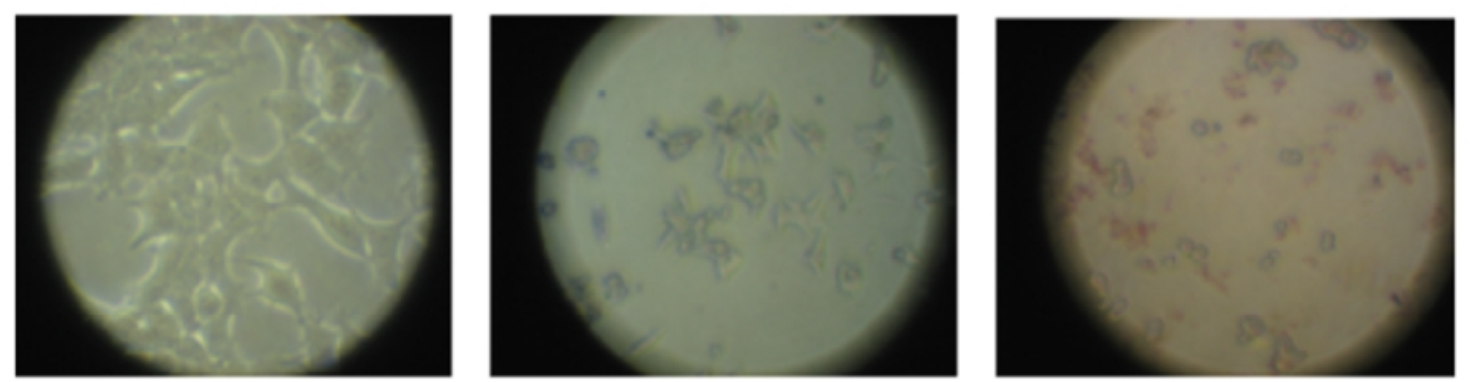

Figure 2: Images of MCF 7 Cells in culture: a) Without any treatment [negative control]; b) Treated with extract [test]; c) Treated with doxorubicin [positive control].

\section{REFERENCES}

1. Kometiani P, Liu L \& Askari A. Digitalis-induced signaling by $\mathrm{Na}+/ \mathrm{K}+-$ ATP ase in human breast cancer cells. Mol. Pharmacol 2005; 67929936.

2. Shiratori O. Growth inhibitory effect of cardiac glycosides and aglycones on neoplastic cells: in vitro and in vivo studies. Gann 1967; 58: 521-528. PMid:5589524

3. Bielawski K, Winnicka $\mathrm{K} \&$ Bielawska A. Inhibition of DNA topoisomerases I and II and growth inhibition of breast cancer MCF-7 cells by ouabain, digoxin and proscillaridin A. Biol. Pharm. Bull 2006; 291493-1497.

4. Lopez-Lazaro $\mathrm{M}$ et al. Digitoxin inhibits the growth of cancer cell lines at concentrations commonly found in cardiac patients. J. Nat. Prod 2005; 68: 1642-1645. http://dx.doi.org/10.1021/np0502261 PMid: 16309315

5. Aiton WT. Calotropis procera: Germplasm Resources Information Network, United States Department of Agriculture; 2001. PMid: 11235917

6. H Akshayan, Narayanan Rita, Kumar G Senthil. Suitability of Calotropis gigantea Extract as a cleaning agent for dairy Storage Unit, IJSER 2012; 3(8).
7. Kumar VL, Roy S. Calotropis procera latex extract affords protection against inflammation and oxidative stress in Freund's complete adjuvant-induced monoarthritis in rats 2007; 47523

8. Smit HF, Woerdenbag HJ, Singh RH, Meulenbeld GJ, Labadie RP, Zwaving JH. Ayurvedic herbal drugs with possible cytostatic activity. J Ethnopharmacol 1995; 47: 75-84. http://dx.doi.org/10.1016/03788741(95)01255-C

9. Sehgal RS, Roy S, Kumar VL. Evaluation of cytotoxic potential of latex of Calotropis procera and podophyllotoxin in Allum cepa root model. Biocell 2006; 30: 9-13. PMid: 16845823

10. Abdel-AzIm NS. Phyto Chemistry 1998; 49(48): 273-275

11. Giorgio Grosa, Gianna Allegrone, Erika Del Grosso. LC-ESI-MS/MS characterization of strophanthin-K. Journal of Pharmaceutical and Biomedical Analysis 2005; 38(11): 79-86. http://dx.doi.org/10.1016/ j.jpba.2004.12.008 PMid:15907623

Cite this article as:

K. Sumangala Bhat and Abhilasha Sharma. Therapeutic potential of cardiac glycosides of Calotropis gigantea for breast cancer. Int. Res. J. Pharm. 2013; $4(6): 164-167$ 